\section{Differing Nursery Production Systems Impact Cost of Planting Oak Species in the Urban Environment}

\author{
Benjamin L. Green ${ }^{1}$, Richard W. Harper ${ }^{1,3}$, and Daniel A. Lass ${ }^{2}$
}

ADDITIONAL INDEX WORDs. balled and burlapped, bare root, cost, in-ground fabric, planting time, pot-in-pot, Quercus rubra, Quercus bicolor

SUMMARY. Urban foresters must be able to accurately assess costs associated with planting trees in the built environment, especially since resources to perform community forest management are limited. Red oak (Quercus rubra) and swamp white oak $(Q$. bicolor $)(n=48)$ that were produced using four different nursery production systems-balled and burlapped (BNB), bare root (BR), pot-in-pot container grown (PIP), and in-ground fabric (IGF)-were evaluated to determine costs of planting in the urban environment. Costs associated with digging holes, moving the trees to the holes, and planting the trees were combined to determine the mean cost per tree: BNB trees cost $\$ 11.01$ to plant, on average, which was significantly greater than PIP (\$6.52), IGF (\$5.38), and BR (\$4.38) trees. Mean costs for BR trees were significantly lower than all other types of trees; IGF trees were less expensive to plant (by \$1.14) than PIP trees, but this difference was not statistically significant $(P=\mathbf{0 . 0 5 8})$. Probabilities that cost per tree are less than specific values also are calculated. For example, the probabilities that IGF and BR can be planted for less than $\$ 8.00$ per tree are 1.00 . The probability that a PIP can be planted for less than $\$ \mathbf{8 . 0 0}$ is $\mathbf{0 . 8 6}$, whereas the probability for a BNB tree is just 0.01. This study demonstrates that the cost of planting urban trees may be affected significantly in accordance with their respective nursery production method.

$\mathrm{I}$ $\mathrm{t}$ is estimated that $90 \%$ of trees that are established in the urban environment in the northeastern United States are produced in the nursery as a field-grown plant where they are dug, wrapped in burlap, and transported to the new planting site as a "BNB" tree (N.L. Bassuk, personal communication). In recent times, other nursery techniques have become increasingly popular, including PIP container-grown, IGF, and BR production systems. Though each method offers advantages and disadvantages, some researchers have speculated that nursery production methods may not significantly limit transplant survival and plant performance (Levinsson, 2013). Factors like tree species selection

We wish to thank the following organizations and individuals for their support: Cathy Neal (University of New Hampshire); Amanda Bayer (Stockbridge School of Agriculture-University of Massachusetts); John Kinchla (Amherst Nurseries); Alan Snow and the Department of Public Works staff (town of Amherst, MA); University of Massachusetts Center for Agriculture, Food and the Environment (CAFE).

${ }^{1}$ Department of Environmental Conservation, University of Massachusetts, 160 Holdsworth Way, Amherst, MA 01003-9285

${ }^{2}$ Department of Resource Economics, University of Massachusetts, 80 Campus Center Way, Amherst, MA 01003-9285

${ }^{3}$ Corresponding author. E-mail: rharper@eco.umass. edu.
(Ferrini and Nicese, 2006), size (Struve et al., 2000), transplant timing (Richardson-Calfee et al., 2004), and post-transplant maintenance (Gilman, 2001; Watson and Himelick, 2013) may be more limiting relative to tree performance and inevitably, the successful long-term "greening" of a community. However, to the urban forester/ tree warden charged with the day-today care of community trees, the most important limiting factor relative to successful tree planting and urban forest management are the resources required to acquire and plant street trees (Stobbart and Johnston, 2012).

With this in mind, the objectives of this study were to build on existing research pertaining to the costs associated with growing trees using different nursery production systems (Lass and Neal, 2014), by providing a more scientifically based understanding of the true costs associated with the planting of urban trees grown using four different nursery production systems (PIP, BNB, IGF, and BR).

\section{Materials and methods}

LOADING AND UNLOADING. A total of 48 trees (2- to 2.5 -inch caliper) consisting of 24 red oak and 24 swamp white oak trees were obtained from the Woodman Horticultural Research Farm-University of New Hampshire (Durham, NH) and Amherst Nurseries (Amherst, MA). All 24 swamp white oak trees were grown at the Research Farm using three production methods: field-grown prepared as $\mathrm{BNB}$ (eight trees), containerized trees grown PIP (eight trees), and IGF (eight trees). All red oak trees were grown at Amherst Nurseries using three methods: field-grown harvested as BNB (eight trees), IGF (eight trees), and field-grown trees that were harvested as BR (eight trees). Trees were loaded by two municipal employees and a nursery employee onto two landscape trailers, a smaller trailer measuring $5 \times 9 \mathrm{ft}$ and a larger trailer measuring $6 \times 12 \mathrm{ft}$ that were towed by a $1 / 2$-ton pickup truck. A tractor (5740; Kubota Corp., Osaka, Japan) was used to load BNB trees as each specimen was estimated to weigh over $300 \mathrm{lb}$. Trees were then rolled into position and secured to the trailer using rope, by the municipal employees. PIP and IGF trees were lifted from the ground by two employees and loaded onto the trailer; one employee was located inside the trailer to position and secure the trees. BR trees were also loaded by hand in like manner, requiring only one individual to lift each tree and another individual to secure the trees on the trailer. The roots of all BR trees were moistened and loosely covered with burlap to help protect against desiccation.

Three individuals unloaded trees at the planting location. A $4 \times 4$ utility vehicle (5600; Bobcat Co., West Fargo, ND) fitted with a 36-inch-wide auger attachment was required to lift and move the BNB trees. One laborer positioned trees on the trailer so that

\begin{tabular}{llll}
\hline $\begin{array}{l}\text { Units } \\
\text { To convert U.S. to SI, } \\
\text { multiply by }\end{array}$ & U.S. unit & SI unit & $\begin{array}{l}\text { To convert SI to U.S., } \\
\text { multiply by }\end{array}$ \\
\hline 0.3048 & $\mathrm{ft}$ & $\mathrm{m}$ & 3.2808 \\
2.54 & inch(es) & $\mathrm{cm}$ & 0.3937 \\
0.4536 & $\mathrm{lb}$ & $\mathrm{kg}$ & 2.2046 \\
0.9072 & ton $(\mathrm{s})$ & $\mathrm{Mg}$ & 1.1023
\end{tabular}


they were accessible by the utility vehicle operator. The second laborer would steady each tree as it was lifted and transported to its location. PIP and IGF trees required two employees (an operator and a laborer) for unloading. The operator drove the pickup truck while the laborer walked beside the trailer unloading each tree at its planting location. BR trees were kept on the trailer under the protection of the tarp until the planting holes had been dug. They were then carried to their planting location. The amount of time it took to load and unload each type of production system was recorded.

The utility vehicle fitted with a 36-inch-wide auger attachment was used to auger each planting hole to a depth of $\approx 2 \mathrm{ft}$. The time that was required to dig each hole was recorded beginning with the auger positioned at the site, until the hole was completely dug and all soil was shaken from the auger. Once a hole was completed, the operator would proceed to the next planting location. Travel time between holes was not recorded because a number of tree locations involved moving the equipment across road intersections and around guardrails.

Planting. Trees were planted in the same suburban area in Amherst, MA, within a short period (3 work days), by the same crew using the same equipment to help minimize the number of external factors that could affect tree planting costs. All trees were installed by two laborers using the same process except in the preparation of the root ball, which differed in accordance with the trees' respective production system. The planting process began with one laborer measuring the distance between the beginning of the root flare and the bottom of the root ball to determine the proper planting depth. This measurement was used to determine if soil needed to be added or removed from the pre-augured hole. The sides of the hole were scarified to facilitate root penetration to the surrounding soil profile and encourage successful tree establishment. The second laborer's job was to prepare the tree by pruning out any dead or damaged branches and to also prepare the root ball in the following manner: BNB - the wire cage and burlap were removed from root ball; PIP - the container was removed detached from root ball and roots were pruned with hand pruners and saw, to minimize presence of remove circling roots; IGF-the fabric bag was removed from root ball; and BR - selective root pruning to remove dead or damaged roots, if needed. The root ball was then placed into the prepared hole. As one laborer held the trunk of the tree perpendicular to the ground, the second would monitor to ensure that the root flare was at ground level, to preclude excess soil from accumulating on top of the tree's structural roots (Arnold et al., 2007; Wells et al., 2006). The hole was then backfilled about halfway and "watered in" using a pump and water tank that was located in the back of the pickup truck, to help ensure that no air pockets were located in the backfilled soil. The hole was then completely backfilled and watered in a second time. Finally, a water well was shaped around the base of the trunk and a 2 - to 3 -inch layer of bark mulch was applied. Recording of the time required to plant each tree commenced when the crew began to prepare the tree for planting by removing burlap or container, and ceased when the tree was completely backfilled and watered.

Planting times were summarized by means, SD, and a five-number summary (minimum, maximum, and quartiles). We first tested for mean planting time differences across the two species of oak trees using a two-sample $t$ test assuming unequal variances. If there was no difference in mean planting time across species, we pooled the species data and tested for differences across all four nursery production methods. Anderson-Darling tests were used to assess normality of the planting time distributions. We tested for differences across tree types in planting time variances and mean planting times. Two-sample F tests were used to test for differences in variances and two-sample $t$ tests assuming different variances as well as pooled data regression analysis were used to test mean planting time differences across treatments. All tests were completed using a $5 \%$ level of significance.

Planting costs. Planting costs per tree were estimated using the data collected for time unloading, digging holes, and planting. Costs were determined by charging each tree for the labor and equipment required to dig holes, to place the tree at the site, and to complete the planting process. The costs to dig all holes included the rental costs for a machine with a 36inch-wide auger attachment and an equipment operator. The town of Amherst, MA, Department of Public Works used a utility vehicle that they owned. The rental rate that we used was for an alternative machine (MT52; Bobcat Co.) with an auger at a quoted rental rate of $\$ 35 / \mathrm{h}$ available at a local rental company (West County Rentals, Hadley, MA) and an operator at the wage rate of $\$ 26 / \mathrm{h}$ (J. Kinchla, personal communication).

The costs of unloading and placing each tree at the planting site included the costs of a pickup truck (F-150; Ford Motor Co., Dearborn, MI) at $\$ 10 / \mathrm{h}$, trailer $(6 \times 12 \mathrm{ft}$ with ramp) at $\$ 3 / \mathrm{h}$, and operator labor and a laborer at the equivalent wage rate of $\$ 13 / \mathrm{h}$ (A. Snow, personal communication). The weight of the BNB trees made it necessary to use the utility vehicle/auger $(\$ 35 / \mathrm{h})$ to move the tree, thus the costs for $\mathrm{BNB}$ trees included that additional expense. Sites that were more easily accessible were chosen for these heavier trees. Due to our need to "select sites" for the BNB trees, we do not report variances for the unloading times and use only the means to estimate costs. Although planting sites were generally an equivalent distance from the road, the mean times reported may underestimate the time required to move the $\mathrm{BNB}$ trees. Planting costs included the costs of two laborers $(\$ 13 / \mathrm{h}$ each) to prepare the holes, prepare the tree root balls, position the trees in the holes, backfill, and water.

Planting times and planting costs varied and to illustrate the relative positions and shapes of the planting time and cost distributions across types of trees, we plotted the estimated distributions. We then determined probabilities for various planting costs to illustrate the uncertainty faced when planting oak trees grown under different nursery production systems. The probabilities represent the areas under the normal probability distributions to the left of a specific cost per tree. These probabilities allow the formation of expectations about planting costs for the different types of trees considered in this study. We present graphs of the distributions for a visual comparison and tables of probabilities to compare the relative uncertainty faced when planting trees from different nursery production methods (Tables 1-5; Figs. 1 and 2). 
Table 1. Comparisons of mean planting times and planting time variation for red oak and swamp white oak trees and among trees from balled and burlap, pot-inpot container, in-ground fabric container, and bare-root production systems.

\begin{tabular}{|c|c|c|c|c|c|}
\hline \multirow{2}{*}{$\begin{array}{l}\text { Tree type and } \\
\text { production system }\end{array}$} & \multirow[b]{2}{*}{$\mathbf{n}$} & Mean & SD & Minimum & Maximum \\
\hline & & \multicolumn{4}{|c|}{ (s/tree) } \\
\hline Red oak & 24 & 613.9 & 248.2 & 340 & 1,140 \\
\hline Swamp white oak & 24 & 700.0 & 222.8 & 394 & 1,336 \\
\hline Balled and burlap & 16 & 901.8 & 182.1 & 685 & 1,336 \\
\hline $\begin{array}{l}\text { In-ground fabric } \\
\text { container }\end{array}$ & 16 & 517.1 & 114.2 & 375 & 781 \\
\hline Pot-in-pot container & 8 & 675.1 & 182.2 & 400 & 978 \\
\hline Bare-root & 8 & 428.6 & 64.9 & 340 & 540 \\
\hline
\end{tabular}

Table 2. Summary of two-sample $t$ test statistics for testing mean planting time differences among trees from balled and burlap (BNB), pot-in-pot container (PIP), inground fabric container (IGF), and bare-root (BR) production systems.

\begin{tabular}{|c|c|c|c|c|}
\hline \multirow{2}{*}{$\begin{array}{l}\text { Tree } \\
\text { type } 1\end{array}$} & \multicolumn{4}{|c|}{ Tree type 2} \\
\hline & $\mathrm{BNB}$ & PIP & IGF & BR \\
\hline $\mathrm{BNB}$ & $\mathrm{NA}^{\mathrm{z}}$ & $\begin{array}{c}2.874^{y} \\
(0.012)^{x}\end{array}$ & $\begin{array}{c}7.161 \\
(0.000)\end{array}$ & $\begin{array}{c}9.283 \\
(0.000)\end{array}$ \\
\hline PIP & & & $\begin{array}{c}2.243 \\
(0.049)\end{array}$ & $\begin{array}{c}3.605 \\
(0.006)\end{array}$ \\
\hline IGF & & & & $\begin{array}{c}2.416 \\
(0.025)\end{array}$ \\
\hline BR & & & & NA \\
\hline
\end{tabular}

${ }^{\mathrm{z}}$ Not applicable-the cell represents comparison of means for trees of the same type.

yTwo-sample $t$ statistics are presented for tests of the hypothesis, $\mathrm{H}_{\mathrm{o}}: \mu_{1}-\mu_{2}=0$.

${ }^{x}$ Two-tail probability values are provided in parentheses below the calculated $t$ statistics.

Table 3. Summary of two-sample F test statistics for testing differences in planting time variances among trees from balled and burlap (BNB), pot-in-pot container (PIP), inground fabric container (IGF), and bare-root (BR) production systems.

\begin{tabular}{lcccc}
\hline \multirow{2}{*}{$\begin{array}{c}\text { Tree } \\
\text { type }\end{array}$} & \multicolumn{3}{c}{ Tree type 2 } \\
\cline { 2 - 5 } BNB & PIP & IGF & BR \\
\hline NA $^{\mathrm{z}}$ & $0.999^{\mathrm{y}}$ & 2.544 & 7.884 \\
& & $(0.468)^{\mathrm{x}}$ & $(0.040)$ & $(0.005)$ \\
PIP & & & 2.547 & 7.892 \\
& & & $(0.061)$ & $(0.007)$ \\
IGF & & & & 3.099 \\
& & & & $(0.068)$ \\
BR & & & & NA \\
\hline
\end{tabular}

${ }^{\mathrm{z}}$ Not applicable-the cell represents comparison of variances for trees of the same type

ywo-sample $F$ statistics for tests of the hypothesis, $\mathrm{H}_{\mathrm{o}}: \sigma_{1}{ }^{2}=\sigma_{2}{ }^{2}$.

${ }^{\times} P$ values are provided in parentheses below the calculated F statistics.

\section{Results and discussion}

Planting time. A key factor in determining the planting cost of an urban tree is planting time, since it determines both labor and equipment costs. While it appeared that there were differences in planting times for red oak and swamp white oak (Table 1), two-sample $t$ tests indicated that the differences were not statistically significant $(P=0.106)$. Thus, we pooled data for the two species of oak and tested for differPlanting times were determined to vary according to the size of the tree and the production system. BNB trees required that the wire basket and burlap be removed, IGF trees required the fabric container be removed from the root ball, and PIP trees were removed from the plastic container. PIP trees sometimes required extensive root pruning to address root girdling. With these differences across types of trees and differences in tree weights and root ball sizes, we observed variation in the time required to plant the trees.

The greatest planting time, on average, was for the $\mathrm{BNB}$ trees at more than $900 \mathrm{~s}$ (Table 1). The mean BNB planting time was significantly greater than mean planting times for all other tree types. The BR trees were planted in less than half that time at $428.6 \mathrm{~s}$, on average. The mean BR planting time was significantly less than mean planting times for all other tree types. IGF trees were planted in 517.1 s and the PIP trees required $675.1 \mathrm{~s}$, on average. The mean planting time for IGF trees was significantly less than the PIP trees $(P=0.049)$.

We also compared the planting time variances by treatments. BNB trees had planting time variances that were significantly greater than IGF $(P=0.040)$ and BR $(P=0.005)$ trees (Table 3 ). Variances for BNB and PIP trees were not statistically different ences across production systems. (both SD were virtually equivalent at $182 \mathrm{~s}$ ). The variance for PIP trees was significantly greater than the variance of BR trees $(P=0.007)$. Although the variance for PIP was much greater than that of the IGF trees, the difference was not significant $(P=0.061)$. Similarly, the variance for IGF trees was greater than the variance for BR trees, but was not significantly greater $(P=0.068)$.

These differences are reflected in the planting time distributions for the four treatments displayed as normal distributions (Fig. 1). The distributions for the BNB and PIP trees are identically shaped but PIP trees are planted much faster, on average. The distribution for the IGF trees is much more compact than the BNB and PIP trees (smaller SD) and has a shorter mean planting time per tree. Finally, the distribution for $\mathrm{BR}$ trees is noted to feature the smallest mean planting time and variance. Comparing these planting time distributions, we can see that the probability of planting a BR within a specified time would be smaller than the probability of planting any other tree type within the same time. For example, the probability that planting a BR tree would take less than $10 \mathrm{~min}(600 \mathrm{~s})$, is clearly much greater than the probability for any other treatment. If an individual were "risk averse" with respect to planting time variability, that individual would first choose to plant BR trees, all else constant. They would then move to the IGF trees next followed by PIP and BNB trees.

Costs of PLANTING. On average, it took 63 s to dig a hole (Table 4). To compute planting costs, all holes were assumed to be in a line along the road with equivalent minimal "travel time" between holes. The time to dig the holes varied depending on the soil and amount of sod (the SD was $24.3 \mathrm{~s}$ ). All trees were assigned the same mean costs for digging holes. On average, the cost of digging a hole with the 36 -inch-wide auger was $\$ 1.06$ and included $63 \mathrm{~s}$ of equipment and operator time (Table 4). The costs of unloading the trees differed by tree production type. BNB trees included the costs of the pickup truck and trailer, the machine to move them to the holes, operator labor, and an additional laborer to help in moving the trees. All other tree types (IGF, PIP, and BR) were 
Table 4. Summary of planting costs by activity for red oak and white oak trees from balled and burlap (BNB), pot-in-pot container (PIP), in-ground fabric container (IGF), and bare-root (BR) production systems.

\begin{tabular}{|c|c|c|c|c|}
\hline \multirow[b]{2}{*}{ Activity } & \multicolumn{4}{|c|}{ Time required and costs per tree } \\
\hline & BNB & PIP & IGF & BR \\
\hline \multicolumn{5}{|l|}{ Preparation-dig holes } \\
\hline Mean time (s/tree) & 63 & 63 & 63 & 63 \\
\hline $\begin{array}{l}\text { Skid steer with } \\
\text { auger }(\$ / \text { tree })^{z}\end{array}$ & 0.61 & 0.61 & 0.61 & 0.61 \\
\hline Operator labor $(\$ / \text { tree })^{\mathrm{yx}}$ & 0.45 & 0.45 & 0.45 & 0.45 \\
\hline Preparation costs $(\$ /$ tree $)$ & 1.06 & 1.06 & 1.06 & 1.06 \\
\hline \multicolumn{5}{|l|}{$\begin{array}{l}\text { Unloading at site-move } \\
\text { trees to holes }\end{array}$} \\
\hline Mean time $(\mathrm{s} / \text { tree })^{\mathrm{w}}$ & 142 & 40 & 40 & 15 \\
\hline $\begin{array}{l}\text { Skid steer with } \\
\text { auger }(\$ / \text { tree })^{z}\end{array}$ & 1.38 & - & - & - \\
\hline Pickup truck $(\$ / \text { tree })^{\mathrm{z}}$ & 0.39 & 0.11 & 0.11 & 0.04 \\
\hline $\begin{array}{l}\text { Trailer-6 } 612 \mathrm{ft} \\
(1.8 \times 3.7 \mathrm{~m}) \\
\text { with } \operatorname{ramp}(\$ / \text { tree })^{\mathrm{z}}\end{array}$ & 0.12 & 0.03 & 0.03 & 0.01 \\
\hline $\begin{array}{l}\text { Unloading equipment } \\
\text { costs }(\$ / \text { tree })^{\mathrm{v}}\end{array}$ & 1.89 & 0.14 & 0.14 & 0.05 \\
\hline Operator labor $(\$ / \text { tree })^{\mathrm{yx}}$ & 1.03 & 0.29 & 0.29 & 0.11 \\
\hline $\begin{array}{l}\text { Labor-one } \\
\text { laborer }(\$ / \text { tree })^{y}\end{array}$ & 0.51 & 0.14 & 0.14 & 0.05 \\
\hline Unloading costs $(\$ /$ tree $)$ & 3.43 & 0.58 & 0.58 & 0.22 \\
\hline \multicolumn{5}{|l|}{$\begin{array}{l}\text { Planting-position tree, } \\
\text { root prune, and backfill }\end{array}$} \\
\hline Mean time (s/tree) & 902 & 675 & 517 & 429 \\
\hline Labor-two laborers $(\$ / \text { tree })^{\mathrm{yu}}$ & 6.51 & 4.88 & 3.73 & 3.10 \\
\hline Planting costs $(\$ /$ tree $)$ & 6.51 & 4.88 & 3.73 & 3.10 \\
\hline $\begin{array}{l}\text { Total preparation, unloading, } \\
\text { and planting costs ( } \$ / \text { tree })\end{array}$ & 11.01 & 6.52 & 5.38 & 4.38 \\
\hline \multicolumn{5}{|c|}{$\begin{array}{l}{ }^{7} \text { Machinery and equipment rental rates based on daily rental are: skid-steer loader with auger }(\$ 35 / \mathrm{h}) \text {, pickup truck } \\
\text { with trailer hitch }(\$ 10 / \mathrm{h}) \text {, and } 6 \times 12 \mathrm{ft} \text { trailer }(\$ 3 / \mathrm{h}) \text {. } \\
{ }^{\mathrm{y}} \text { Wages for the machinery operator and laborers are } \$ 26 / \mathrm{h} \text { and } \$ 13 / \mathrm{h} \text {, respectively. } \\
{ }^{{ }^{2} T h e} \text { operator is assumed to drive the truck and trailer and skid-steer auger. } \\
\text { "Wole positions were along a suburban road and trees were not placed randomly; PIP, IGF, and BR trees carried by } \\
\text { hand to holes; BNB trees placed at most easily reached holes using skid-steer auger. } \\
\text { "Equipment costs include the allocated costs of a skid-steer auger, pickup truck, and trailer for the time required to } \\
\text { move the tree to the prepared hole. } \\
\text { "Laborers are assumed to assist with unloading, positioning trees, and back filling holes. Two laborers were used to } \\
\text { position the tree and back fill during planting. }\end{array}$} \\
\hline
\end{tabular}

Table 5. Estimated probabilities that total preparation, unloading, and planting costs for red oak and swamp white oak trees from balled and burlap (BNB), potin-pot container (PIP), in-ground fabric container (IGF), and bare-root (BR) production systems are less than the given values for costs per tree $(x)$.

\begin{tabular}{|c|c|c|c|c|c|c|c|c|c|}
\hline & \multicolumn{9}{|c|}{ Costs per tree $(\$ / \text { tree })^{\mathrm{z}}$} \\
\hline & $\$ 4.00$ & $\$ 5.00$ & $\$ 6.00$ & $\$ 7.00$ & $\$ 8.00$ & $\$ 9.00$ & $\$ 10.00$ & $\$ 11.00$ & $\$ 12.00$ \\
\hline & \multicolumn{9}{|c|}{$P$ actual cost $<x^{\mathrm{y}}$} \\
\hline $\mathrm{BNB}$ & 0.000 & 0.000 & 0.000 & 0.002 & 0.014 & 0.072 & 0.231 & 0.496 & 0.763 \\
\hline PIP & 0.034 & 0.135 & 0.353 & 0.636 & 0.858 & 0.964 & 0.994 & 0.999 & 1.000 \\
\hline IGF & 0.067 & 0.340 & 0.750 & 0.961 & 0.998 & 1.000 & 1.000 & 1.000 & 1.000 \\
\hline $\mathrm{BR}$ & 0.270 & 0.839 & 0.995 & 1.000 & 1.000 & 1.000 & 1.000 & 1.000 & 1.000 \\
\hline
\end{tabular}

${ }^{\mathrm{z}} \mathrm{A}$ range of possible costs per tree are presented that are representative of the costs per tree from our samples. y Probabilities are the areas under the normal distributions (Fig. 2) to the left of the given values for costs per tree denoted as $x$. The normal probability distribution function is integrated up to and including the specific values $(x)$ given in row three of the table above $(\$ 4.00-\$ 12.00)$. For example, for IGF trees, $P$ actual cost $<\$ 6=\int_{-\infty}^{\$ 6} \frac{1}{\sigma \sqrt{2 \pi}} \cdot e^{-\left(\frac{(86-\mu)^{2}}{2 \sigma^{2}}\right)}=0.75$. handed from the trailer (by the operator) and carried to the hole (by the laborer). Thus, the costs for all other trees reflected the costs of the truck and trailer, the operator (assumed to drive the truck) and an additional laborer. The cost per tree for BNB trees was $\$ 3.43$, the cost of the IGF and PIP trees was $\$ 0.58 /$ tree, and the BR trees cost $\$ 0.22 /$ tree (Table 4 ).

The final component of costs was planting the trees. The planting times for BNB trees were noted to be statistically greater than the times for all other tree types and that time translates to a planting cost per tree of $\$ 6.51$. The BNB planting costs per tree were $\$ 1.64, \$ 2.78$, and $\$ 3.42$ greater than PIP, IGF, and BR trees, respectively. Combining the variation due to digging holes and planting, 95\% confidence intervals were determined for each tree type. Thus, the average cost of planting a tree derived from each production system was determined to be: $\$ 11.01 \pm \$ 0.74$ (BNB), \$4.38 \pm \$0.37 (BR), \$6.52 \pm $\$ 0.82$ (PIP), and $\$ 5.38 \pm \$ 0.49$ (IGF).

Distributions' locations on the axis (Fig. 2) reflect the mean costs and their relative shapes reflect cost variations that arise from digging holes and planting the trees. Shapes primarily reflect the shapes for planting time distributions (Fig. 1), but additional cost variation of digging holes is also included. The greater mean costs of unloading the BNB trees further separate that distribution from the distributions for the remaining three production systems (PIP, IGF, and BR).

BR cost distribution will yield greater probabilities of planting a tree within a given time than all other distributions (Fig. 2). The IGF distribution will yield greater probabilities for a given time than the PIP and BNB distributions (Fig. 2). Given the cost distributions that were estimated in this study, we ask, for example: "what is the chance (probability) that a tree can be planted for less than \$4.00?" Only the BR trees have a substantial probability at $27 \%$ (Table 5). There is virtually no chance that a BNB tree can be planted for less than $\$ 4.00$ given the conditions under which the trees in this study were planted. As we increase the cost per tree, the probabilities increase for all the tree types. It is nearly a certainty that a BR tree can be planted for less than $\$ 6.00$. 


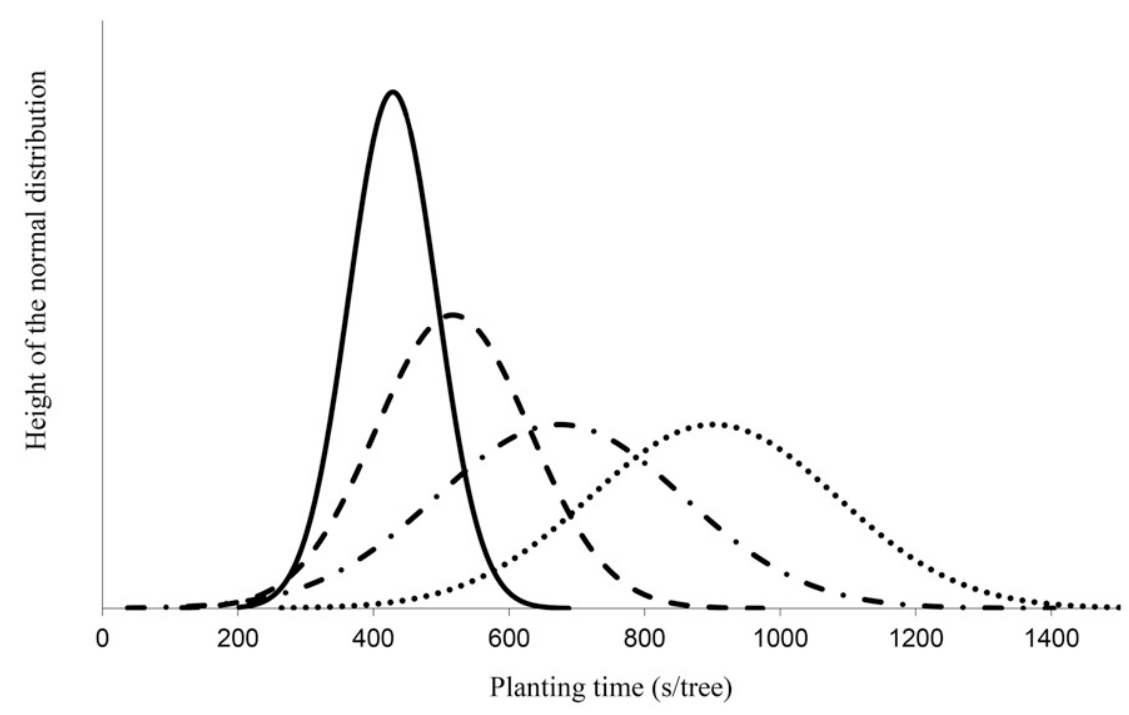

............ BNB

- - - $\quad$ IGF

$-\cdots \quad$ PIP

$\longrightarrow \mathrm{BR}$

Fig. 1. Comparison of planting time distributions for oak trees from balled and burlap (BNB), in-ground fabric container (IGF), pot-in-pot container (PIP), and bare-root (BR) production systems. Taller distributions indicate less variation in planting times per tree for that production system.

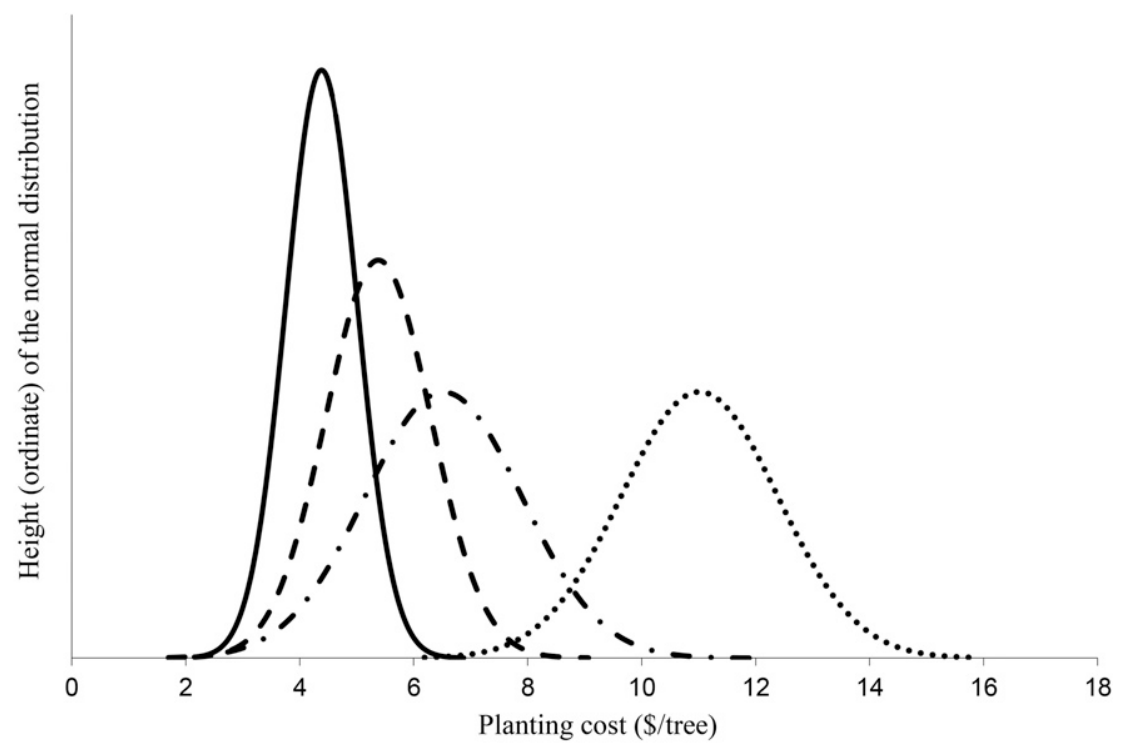

BNB....... $\quad \mathrm{BN}$

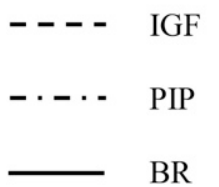

Fig. 2. Comparison of planting cost distributions for oak trees from balled and burlap (BNB), in-ground fabric container (IGF), pot-in-pot container (PIP), and bare-root (BR) production systems. Taller distributions indicate less variation in planting times per tree for that production system.
About $75 \%$ of the IGF trees and over $35 \%$ of the PIP trees can be planted for less than $\$ 6.00$, but the probability of planting a BNB tree for $\$ 6.00 /$ tree or less is still virtually zero. The probability of planting a BNB tree exceeds zero at $\$ 7.00 /$ tree and above, and reaches a probability of 0.763 at $\$ 12.00 /$ tree. At costs per tree of $\$ 9.00$ or less, virtually all $\mathrm{BR}$, IGF, and PIP trees can be successfully planted; $\approx 7.2 \%$ of the BNB trees could be planted for less than $\$ 9.00$.

\section{Conclusion}

There are substantial differences in the costs of planting trees and in this study we show that those costs can differ significantly due to nursery production methods. Mean planting times for BNB trees were estimated to be $902 \mathrm{~s}$, whereas planting times were 675,517 , and 429 s for PIP, IGF, and BR trees, respectively. Mean comparison showed that when hole preparation was complete and that all trees were placed next to the holes, the mean planting time for $\mathrm{BNB}$ trees was significantly longer than mean times for PIP, IGF, and BR trees. The mean BR planting time was significantly shorter than all other treatments and that the IGF mean planting time was significantly shorter than the PIP mean planting time.

The mean cost per tree for $\mathrm{BNB}$ trees at \$11.01 was significantly greater than the mean costs for PIP (\$6.52), IGF (\$5.38), and BR $(\$ 4.38)$ trees. Mean costs for BR trees were significantly lower than all other treatments. Comparing the mean costs for PIP and IGF trees, we estimated that the IGF trees were less expensive to plant by $\$ 1.14$, and that difference was not statistically important at the $5 \%$ level of significance $(P=$ $0.058)$. Since variation in planting sites may be widespread, travel time was not a consideration as part of this study, nor was market purchase price of the trees relative to the differing production systems. Long-term maintenance costs (e.g., watering, mulching, pruning, weed management, etc.) were also outside of purview of this research but also would be excellent consideration for further study. For the opportunity to see the research specimen trees and to compare root systems from the different nursery production methods, visit www.urbanforestrytoday.org and click on "videos." 


\section{Research Reports}

\section{Literature cited}

Arnold, M.A., G.V. McDonald, D.L. Bryan, G.C. Denny, W.T. Watson, and L. Lombardini. 2007. Below-grade planting adversely affects survival and growth of tree species from five different families. Arboricult. Urban For. 33(1):64-69.

Ferrini, F. and F.P. Nicese. 2006. Effect of container type nursery techniques on growth and chlorophyll content of Acer platanoides L. and Liquidambar styraciflua L. plants. J. Food Agr. Environ. 4(3/4): 209-213.

Gilman, E.F. 2001. Effect of nursery production method, irrigation, and inoculation with mycorrhizae-forming fungi on establishment of Quercus virginiana. J. Arboricult. 27(1):30-38.

Lass, D. and C. Neal. 2014. Getting to the roots: Costs of growing river birch in different production systems. Amer. Nurseryman 214(8):12-18.

Levinsson, A. 2013. Post-transplant shoot growth of trees from five different production methods is affected by site and species. Arboricult. Urban For. 39(5): 201-210.

Richardson-Calfee, L., J.R. Harris, R.H. Jones, and J.K. Fanelli. 2004. Seasonal effects of transplanting on northern red oak and willow oak. J. Environ. Hort. 22(2):75-79.
Stobbart, M. and M. Johnston. 2012. A survey of urban tree management in New Zealand. Arboricult. Urban For. 38(6): 247-254.

Struve, D.K., L. Burchfield, and C. Maupin. 2000. Survival and growth of transplanted large-and small-caliper red oaks. J. Arboricult. 26(3):162-169.

Watson, G.W. and E.B. Himelick. 2013. The practical science of planting trees. Intl. Soc. Arboricult., Champaign, IL.

Wells, C., K. Townsend, J. Caldwell, D. Ham, E.T. Smiley, and M. Sherwood. 2006. Effects of planting depth on landscape tree survival and girdling root formation. Arboricult. Urban For. 32(6): 305-311. 